\title{
CHARACTERISTICS AND DEVELOPMENT OF PROGRAM BUDGETING IN SELF- GOVERNING REGION
}

\author{
Viktor Šoltés ${ }^{1}$, Katarína Štofková
}

\begin{abstract}
The foundation enabling the management of each public administration entity is the budget. Public administration bodies in the Slovak Republic also include self-governing regions among others. Budgets for these regions are categorized into two parts-revenue and expenditure. Expenditures are broken down into different areas (programs) that pursue common goals and objectives. Programs are usually divided into sub-programs and components. Part of the program budgeting deployment incorporated issuance of methodological procedures; these described model cases on how to create the program budget. Yet, these procedures are not binding. As a part of the research in 2013, the final accounts of self-governing regions of the Slovak Republic were analyzed. Division of individual programs and the amount of funding were determined. It is considered appropriate to create some form of general binding regulation defining programs content. This is to be done by considering the clarity and further statistical processing. Given the findings and bearing in mind five years' worth of program budgeting operation in local government bodies, it is only appropriate to consider the implementation of changes in program budgeting and provide enhanced transparency.
\end{abstract}

JEL Classification Numbers: H75, H76, R50, DOI: http://dx.doi.org/10.12955/cbup.v3.583

Keywords: Self-governing region, program budgeting, expenditures, final account

\section{Introduction}

Public service subjects in the Slovak Republic are required to manage their own budget in which the content and structure are defined by various acts. The most important is the Act no. 523/2004 "Coll. of Budget Rules of the Public Service,” which is the basis for other acts, regulations, guidelines, and directives (National Council, 2004a). Regional self-administration subjects, in which municipalities and self-governing regions shall be included, are applied a separate Act no. 583/2004 "Coll. of Budgetary Rules of the Regional Self-Administration,” which regulates the preparation and approval of the budget and the final account (National Council, 2004b).

In addition, the budget also contains the aims and objectives, which will be subject to budget expenditures implementation. Program budgeting is a reallocation of resources to various areas according to common objectives. It is, therefore, a system based on tasks and activities planning of the regional self-administration subjects and allocation of available financial funds to various programs. Programs can be subdivided into subprograms and components (Ministry, 2013). This article presents an analysis of the budgets of self-governing regions and proposals for program budgeting coordination.

\section{Regional self-administration and budgets}

The regional self-administration in the Slovak Republic consists of two levels: the local self-government, which represents municipalities; the regional self-government, which represents self-governing regions. These components of the regional self-administration are defined by the Constitution of the Slovak Republic as an independent, self-governing, administrative units, which are also legal entities with their own property and funds (Štofko, 2011).

\footnotetext{
1 Ing. Viktor Šoltés, Faculty, Faculty of Security Engineering, University of Žilina, Slovakia, Viktor.Soltes@fbi.uniza.sk.

${ }^{2}$ doc. Ing. Katarína Štofková, Faculty of Operation and Economy of Transport and Communication, University of Žilina, Slovakia, Katarina.stofkova@fpedas.uniza.sk
} 




Self-governing region may be considered as an administrative region bringing together the residents within its territory. Seats of the self-governing regions are regional capitals, after which these selfgoverning regions are named. Regional capitals are administrative, economic, transport, and cultural centers of the regions. There are eight regions in Slovakia. The organs of self-governing regions are regional parliament and Chairman of the self-governing region. The Chairman represents the Region from the outside, and he is elected directly by the residents of the Region according to Act no. $303 / 2001$ on elections to organs of self-governing regions. He is a statutory body of the Region when he makes decisions in regard to matters related to property law, labor law, and other selected matters. Regional Parliament is a representative body of the self-governing region constituted by Law-Act no. 302/2001. The Parliament comprises of the Representatives elected directly from elections. Chairman of the self-governing region is the Chairman of the Regional Parliament as well. His primary function is to make decisions on cardinal tasks of the self-governing region. Self-governing regions have their own assets and financial funds managed in accordance with their budget.

The Chairman's proposal on the self-governing region budget is approved by the Regional Parliament. Due to various unforeseen circumstances during the year, there is a need to modify the budget. This is the reason why the budget does not contain numerical information in which the funds were actually spent. Therefore, self-governing regions are required to prepare and approve the final account for the previous year. This account reliably and accurately reflects the actual revenue, as well as the expenditure of the programs.

The budget is a fundamental tool of financial management in the relevant year, and it is governed by the funding of the tasks and functions of the body in any given year. The budget of regional selfadministration subjects shall be established for a period of three years and shall include the income and expenditure side. This revenue may be current and capital costs. Current revenues include tax revenues (local taxes and fees) and non-tax revenues (donations, administration and management fees, subsidies, etc.) (Štofková, Rostášová, Štofko, \& Štofková, 2012).

Capital revenue is income from the sale of movable and immovable property. Analogously, regional self-administration expenditure is divided into current expenditures (funds used for the normal operation of the entity) and capital expenditures (investments in property, from which it will benefit in the coming years) (Ministry, 2015).

\section{Program budgeting of self-governing regions}

The program budgeting in Slovakia was introduced for the first time in 2004 at the central administration. Five years later, in 2009, it was also introduced in the regional self-administration. Municipalities and self-governing regions have to share their expenses among the various programs. It was the need for having the possibility to carry out the operational budget editing that led to program budgeting. For a successful, fast, and smooth implementation of program budgeting in regional self- 
administration, the Ministry of Finance of the Slovak Republic published a methodological tool, which consisted of four documents, implementation of various projects, and organization of seminars and workshops (Kaduková, 2011).

The structure of the program budget is not generally binding by legal regulations. Nevertheless, allocation of expenses to 14 programs is recommended at the level of self-governing regions:

1. Planning, Management, and Control

2. Promotion and Marketing

3. Internal Services

4. Services for Citizens

5. Security

6. Communications

7. Transport
8. Education

9. Sport

10. Culture

11. Social Services

12. Environment for Life

13. Health

14. Administration (Ministry, 2008)

\section{Analysis of program budgeting of self-governing region}

The analysis refers to 2013 in which the final accounts were endorsed. Some programs have been used in the budgets of all self-governing region. That included, for example, some programs such as Education, Social Services, Transport, and Communications. The expenditure associated with these programs together accounted for more than 80 percent of the expenditure of the entire self-governing region. On the contrary, some programs have been at the periphery and were not allocated any funds, such as the program of Security, Health, Tourism, etc. Impartially, it may be concluded that programs, such as security, are provided and funded more from the state budget and the budgets of municipalities located within the region.

Based on the analysis of the program budgets, we proved that no self-governing region put the stated program structure into practice in 2013. Depending on the aims, objectives, and priorities of individual self-governing region, some programs were jointed together; some programs were omitted; or other programs were created. In addition, there are no directives that would accurately specify the activities that could be included within various programs. For this purpose, for example, Bratislava self-governing region indicated subprogram "Legal Services" in the "Planning, Management, and Control," while other self-governing regions included these services in sub-program "Internal Services.”

Despite these difficulties in analyzing the final accounts of the self-governing regions, thanks to the clear division of program structures and sub-elements, it is possible to design a 10-program structure for self-governing regions:

- Program 01: Planning, Management, and Control—expenditure associated with the agencies, organs of self-governing region, foreign and regional cooperation, financial management, monitoring, planning and regional development;

- Program 02: Promotion, Marketing and Tourism—presentation of the region, promotion;

- Program 03: Internal and Security Services_-property management, information technology, legal services, archives, transportation, security, and civil protection;

- Program 04: Communications;

- Program 05: Transportation;

- Program 06: Education and Sport; 
- Program 07: Culture;

- Program 08: Social Services;

- Program 09: Health;

- Program 10: Administration—support action, interest payments and commitments.

Table 1: Expenditures of Self-governing regions for each program in 2013

\begin{tabular}{|c|c|c|c|c|c|c|c|c|c|c|}
\hline 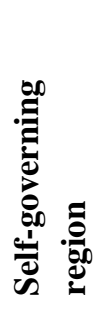 & 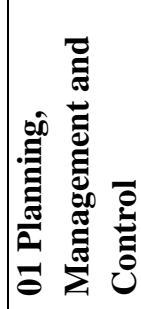 & 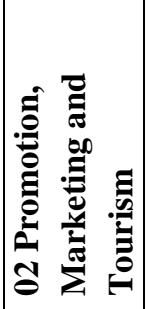 & 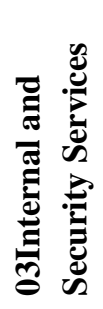 & 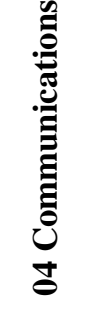 & 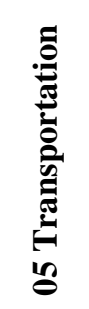 & 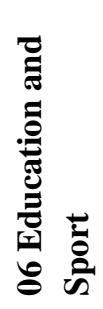 & $\begin{array}{l}\stackrel{U}{\Xi} \\
\stackrel{\Xi}{\Xi} \\
\text { 品 }\end{array}$ & 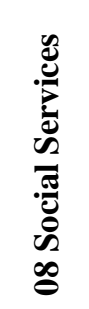 & 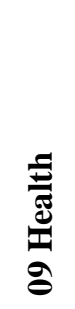 & 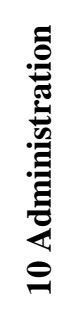 \\
\hline BA & $4 \%$ & $1 \%$ & $6 \%$ & $12 \%$ & $11 \%$ & $40 \%$ & $3 \%$ & $20 \%$ & $0 \%$ & $4 \%$ \\
\hline TT & $4 \%$ & $0 \%$ & $2 \%$ & $10 \%$ & $10 \%$ & $43 \%$ & $4 \%$ & $17 \%$ & $2 \%$ & $8 \%$ \\
\hline TN & $5 \%$ & $1 \%$ & $2 \%$ & $9 \%$ & $15 \%$ & $41 \%$ & $3 \%$ & $16 \%$ & $0 \%$ & $8 \%$ \\
\hline NT & $1 \%$ & $0 \%$ & $3 \%$ & $12 \%$ & $9 \%$ & $42 \%$ & $6 \%$ & $21 \%$ & $2 \%$ & $4 \%$ \\
\hline ZA & $9 \%$ & $0 \%$ & $1 \%$ & $6 \%$ & $9 \%$ & $46 \%$ & $4 \%$ & $20 \%$ & $1 \%$ & $4 \%$ \\
\hline BB & $9 \%$ & $0 \%$ & $1 \%$ & $9 \%$ & $19 \%$ & $37 \%$ & $4 \%$ & $17 \%$ & $0 \%$ & $4 \%$ \\
\hline KE & $3 \%$ & $0 \%$ & $2 \%$ & $12 \%$ & $8 \%$ & $45 \%$ & $12 \%$ & $15 \%$ & $0 \%$ & $3 \%$ \\
\hline PO & $4 \%$ & $0 \%$ & $1 \%$ & $11 \%$ & $11 \%$ & $47 \%$ & $6 \%$ & $18 \%$ & $0 \%$ & $2 \%$ \\
\hline
\end{tabular}

Source: Authors

Education and Sports program represents approximately 40 percent of the self-governing regions budgets. Through this program, self-governing regions fund secondary schools, secondary vocational and technical schools, sports facilities, recreational centers, and other educational institutions located within their territory. Approximately 20 percent of the expenditure is allocated into Social Services program through which social housing, retirement homes, as well as the overall care of people in need are provided. Significant items also include Transport and Communications, based on the co-financing of bus and railway services, repair and construction of roads, pavements, etc. These two programs, which are the same as the previous case, spent an average of 20 percent of all expenditure. On the contrary, the least amount of funding went into the programs of Health Services, Promotion Marketing and Tourism.

Some programs, which should be a part of the program budget of self-governing regions, received no or only minimal funding. It was the Sports program, which was merged together with the Education program. Similarly, for the Security program of self-governing regions, only a small part of their budget was allocated, and, therefore, it should be fused with Internal Services. The primary reason that some programs of self-governing regions were not fund was the insufficient competence. An example may be the Security program, whose primary objective is to protect people and property. At the national level, this role is performed by the Police, which is financed from the state budget. At the municipal level, it is a municipality police, which is financed from the municipal budget. That is why the Security program supports municipality budgets more than self-governing budgets.

Figure 2 shows the percentage of funds distributed through all the self-governing regions. For comparison, Figure 3 shows the allocation of funds in Košice self-governing region. 
CBU I NTERNATI ONAL CONFERENCE ON I NNOVATION, TECHNOLOGY TRANSFER AND EDUCATION

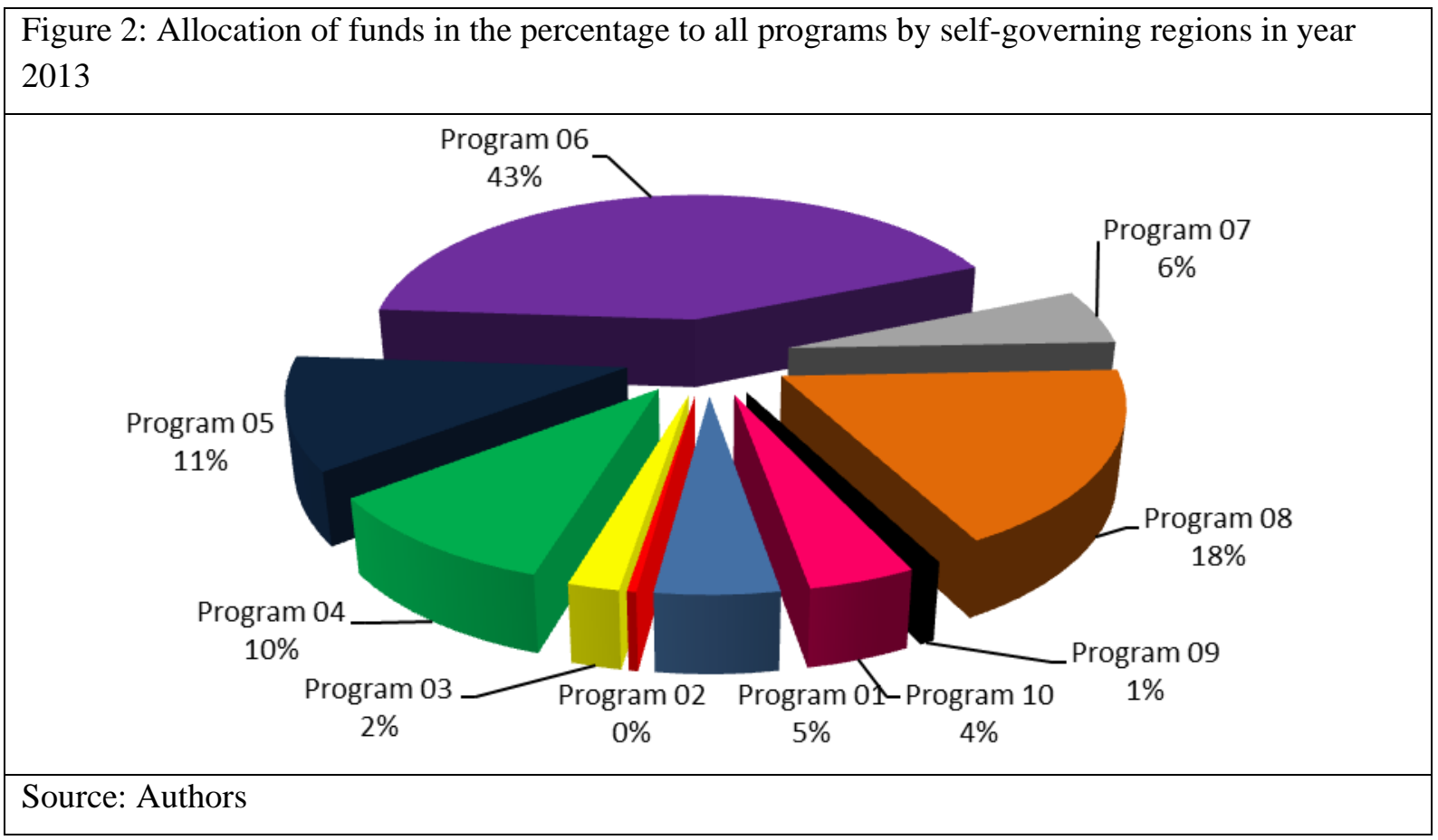

Košice self-governing region, among all regions, spent most of the funds on the Culture program. This is due to the fact that the Košice city was the European Capital of Culture. In connection with this fact, several projects were implemented by the support of the self-governing region. Expenditure spent on other programs were not significantly different in every self-governing region.

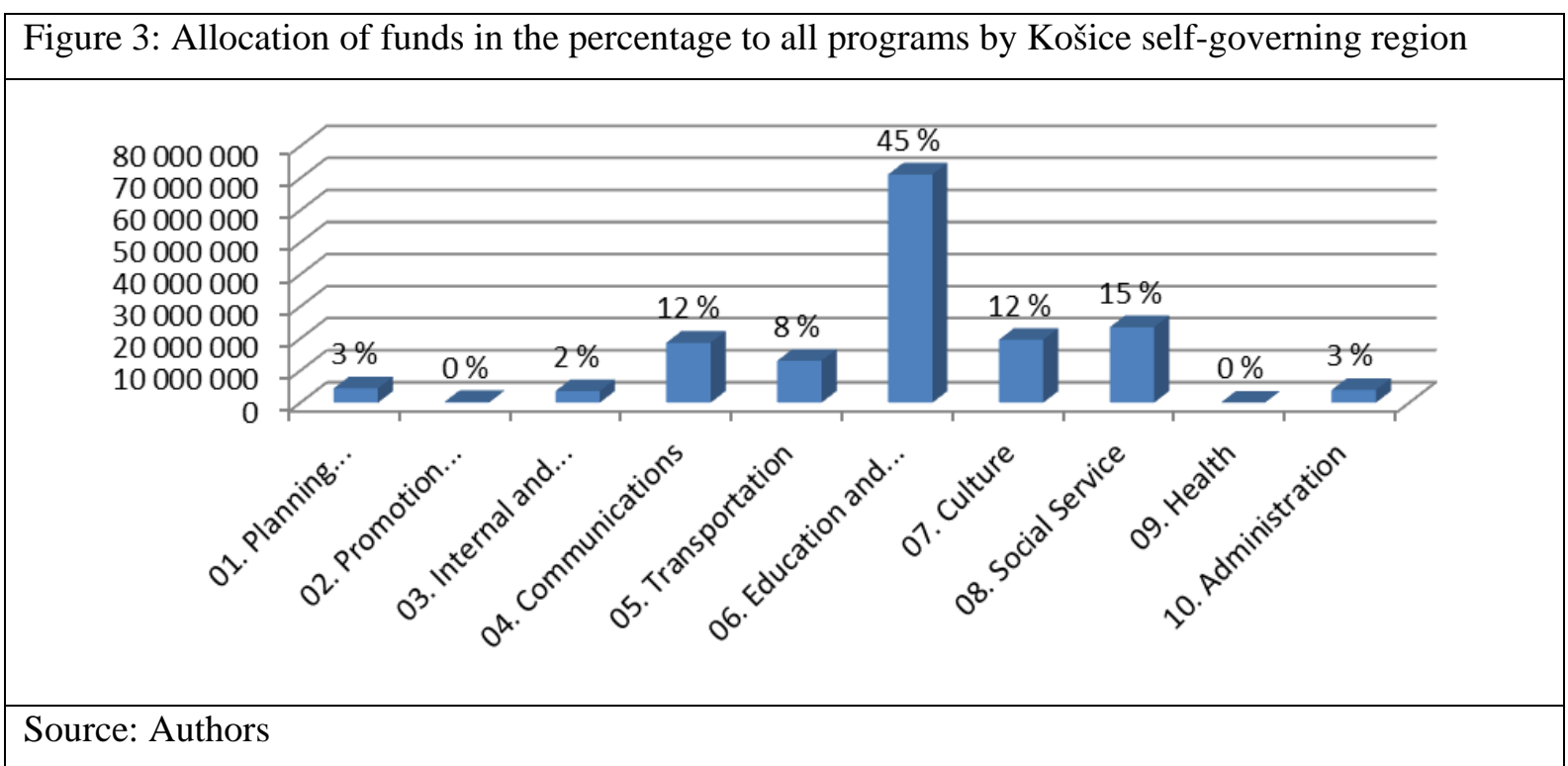

\section{Conclusion}

To increase the effectiveness of program budgeting implementation, the Ministry of finance issued some methodical tools with sample cases to generate program budget. These methodological tools are not universally binding, and, thus, various self-governing regions could create programs according to their needs. Therefore, a comparison of self-governing regions budgets is possible only after a detailed observation and analysis of these budgets.

After a five-year operation of program budgeting at the regional self-administration, one might begin to consider specific changes to make program budgeting more effective, transparent, and unified. 
From the statistical point of view, it would be possible to consider an issuance of regulation that is generally binding. This regulation will define the quantity and the programs that should have a program budget at local, regional, and central administration. It will also dictate the kind of subprograms and elements that should be addressed in the program. In this regard, the program budgeting would have far greater significance, better accessibility, and comprehensibility of the specialists and the public.

\section{Acknowledgment}

This paper was undertaken as part of the research project VEGA 1/0895/13, VEGA 1/787/14, VEGA 1/0175/14, and VEGA 1/0733/15.

\section{References}

National Council of the Slovak Republic [National Council] (2004a). Act no. 523/2004 (2004). Coll. of Budget Rules of the Public Service. [Zákon č. 523/2004 Z. z. o rozpočtových pravidlách verejnej správy].

National Council of the Slovak Republic [National Council] (2004b). Act no. 583/2004 (2004). Coll. of Budgetary Rules of the Regional Self-Administration [Zákon č. 583/2004 Z. z. o rozpočtových pravidlách územnej samosprávy].

Final accounts of self-governing regions of the Slovak republic in 2013 [Final accounts] (2003). Záverečné účty vyšších územných celkov Slovenskej republiky za rok 2013.

Kaduková, E. (2011). Implementation of program budgeting in regional self-administration. [Implementácia programového rozpočtovania $\mathrm{v}$ rozpočtovom procese územnej samosprávy]. (Obecné noviny). Retrieved March, 1, 2015, from http://www.inprost.sk/implementacia-programoveho-rozpoctovania-v-rozpoctovom-procese-uzemnej-samospravy

Ministry of finance of the Slovak Republic [Ministry] (2008). Featured examples of program structures. [Vzorové príklady programových štruktúr]. Retrieved February 28, 2015, from http://rozpocet. finance.gov.sk/archive/file/skoliacematerialy/VUC_BA/VUCBA_Vzory_prog_struktur.pdf

Ministry of finance of the Slovak Republic [Ministry] (2013). Program budgeting of regional self-administration. [Programové rozpočtovanie územnej samosprávy]. Retrieved February 28, 2015, from http://www.finance.gov.sk/Default.aspx?CatID=6487

Ministry of finance of the Slovak Republic [Ministry] (2015). How budged looks like? [Ako vyzerá rozpočet?]. Retrieved February 28, 2015, from http://www.rozpocet.sk/app/homepage/oRozpocte/akoVyzeraRozpocet

Štofková, J., Rostášová, M., Štofko, S., \& Štofková, K. (2012). Financie a finančné riadenie [Finance and Financial Management]. Žilina: Žilinská univerzita. 